\title{
Killer Cell Immunoglobulin-Like Receptor 2DL2
}

National Cancer Institute

\section{Source}

National Cancer Institute. Killer Cell Immunog/obulin-Like Receptor 2DL2. NCI Thesaurus. Code C129038.

Killer cell immunog lobulin-like receptor 2DL2 (348 aa, $\sim 38 \mathrm{kDa}$ ) is encoded by the human KIR2DL2 gene. This protein plays a role in the inhibition of natural killer cell activity. 